\title{
The Significance of Bradycardia in Anorexia Nervosa
}

\author{
Malka Yahalom, MD, DSc, FICA ${ }^{1}$ Marcelo Spitz, MD ${ }^{2}$ Ludmila Sandler, MD ${ }^{2}$ Nawaf Heno, MD \\ Nathan Roguin, $\mathrm{MD}^{4}$ Yoav Turgeman, $\mathrm{MD}^{1,4}$
}

${ }^{1}$ HaEmek Medical Center, Heart Institute, Afula, Israel

2 Department of Children and Psychiatry, Western Galilee Hospital, Nahariya, Israel

3 Department of Pediatrics, Western Galilee Hospital, Nahariya, Israel

${ }^{4}$ Rappaport School of Medicine, Technion, Haifa, Israel

\begin{abstract}
Address for correspondence Yoav Turgeman, MD, HaEmek Medical Center, Yithak Rabin Avenue 18101, Afula, Israel

(e-mail: Yoav_t@clalit.org.il).
\end{abstract}

Int J Angiol 2013;22:83-94.
One Friday evening, during routine work, I was called to the Children and Psychiatry Department to check a 17-year-old girl, with the diagnosis of anorexia nervosa (AN), because of bradycardia (heart rate (HR) of $38 / \mathrm{min}$ ). A month later, a friend of mine asked me to check her 16-year-old daughter who has lost weight and has HR of $47 / \mathrm{min}$. At that time, I realized that not all physicians (in hospitals, the community, or in the military service) are acquainted with the simple, easy to check physical sign of bradycardia in AN, and thus I became involved and decided to collect data concerning this issue.

Eating disorders, and particularly AN, confer a long-lasting increase in morbidity and mortality especially among young adults. It is a life-threatening disorder, with a significant risk for sudden death (5 to 20\%) due to severe cardiovascular complications. It is a generalized disorder that affects multiple organ systems, such as skeletal bones, linear growth, brain development, and fertility functions. Previous reports point- ed out conflicting evidence concerning its reversibility upon treatment. $^{1-8}$

AN carries the highest mortality rate of all psychiatric disorders, mostly due to sudden unexpected cardiac arrhythmic death. ${ }^{9,10}$ Studies have disclosed a mortality rate of up to $20 \%{ }^{11}$ Cardiac arrest secondary to electrolytic disturbances, and $\mathrm{QT}_{\mathrm{c}}(\mathrm{QT}$ corrected to $\mathrm{HR}$ ) interval prolongation (secondary/primary) were recorded among AN patients. ${ }^{12,13}$

The mechanism of sudden death in AN is obscure and is attributed to sudden arrhythmic death. Terminal ventricular tachyarrhythmias (VT) were documented in AN patients, by Isner et al, ${ }^{14}$ with long QT interval prolongation on electrocardiography (ECG), such as sudden death in liquid-protein dietary, that may result from VT, related to QT interval prolongation.

The QT prolongation in Isner's patients was attributed to hypothalamic-pituitary disturbances and to alteration in
Copyright $(2013$ by Thieme Medical Publishers, Inc., 333 Seventh Avenue, New York, NY 10001, USA. Tel: +1(212) 584-4662.
DOI http://dx.doi.org/ 10.1055/s-0033-1334138. ISSN 1061-1711. 
sympathetic-parasympathetic tone. Eckardt et al $^{15}$ described in detail the mechanism of lethal VT of torsade de pointes, which simulated conditions that are likely to exist in the clinical setting of torsade de pointes in animal models, such as bradycardia and hypokalemia.

In vivo, in canine and rabbit models, torsade-like polymorphic VT had been induced by administration of various drugs -to mimic the clinical situation.

It was apparent to them that the first beats of torsade occurred due to early afterdepolarization and triggered activity. They suggested re-entry, based on inhomogeneity of refractoriness, as the underlying mechanism.

Early identification of the disorder is therefore essential for reducing disabling complications and preventing premature death.

The objective of the present study was to summarize and identify cardiac rhythm disorders in a series of consecutive hospitalized adolescent patients with AN, and to verify the clinical significance of bradycardia in this entity. More broadly, we intended to raise or increase the awareness of the possible diagnosis of AN, in young patients with weight loss, displaying bradycardia or new cardiac disorders.

\section{Patients and Methods}

The clinical data of 23 consecutive patients (20 females) hospitalized with the diagnosis of AN during the years 2006 to 2009 were collected and summarized as a retrospective observational study. All patients were free of other illness and without medication on admission.

On admission, medical history, physical examination, a standard 12-lead ECG, and routine laboratory data (hematological, biochemistry tests), including endocrinology test (thyroid-stimulating hormone $\mathrm{IU} / \mathrm{mL}$ ) were performed. A transthoracic echocardiogram (two-dimensional Doppler) examination and Holter ECG recordings were also obtained. The study had been approved by the local hospital committee for human rights.

AN was defined according to the Diagnostic and Statistical Manual of Mental Disorders, Fourth Edition (DSM-IV, 1995). ${ }^{16}$ The criteria for AN were as follows: (1) refusal to maintain body weight at or above a minimally normal weight for age, or weight loss leading to maintenance of body weight less than $85 \%$ of the expected; (2) intense fear of gaining weight or becoming fat; (3) postmonarchial female amenorrhea, that is, absence of at least three consecutive menstrual cycles.

Our criteria for hospitalization were as follows: (1) Body mass index (BMI) less than $17 \mathrm{~kg} / \mathrm{m}^{2}$; or (2) bradycardia less than $50 \mathrm{bpm}$; or (3) failure to persist or respond to outpatient treatment.

Mitral valve prolapse (MVP) was defined clinically and echocardiographically, as the clinical findings of mid-systolic click or click and late systolic murmur do not always exist on physical examination. ${ }^{17}$

The diagnosis of MVP was based on parasternal long-axis view echocardiography and was defined as systolic displacement ( $2 \mathrm{~mm}$ ) of one or both mitral leaflets into the left atrium, below the plane of the mitral annulus. ${ }^{18}$
QT interval and $\mathrm{QT}_{\mathrm{c}}$ were measured from ECG.

Our retrospective data collection did not include HR variable parameters and QT dispersion, at that time. Our retrospective data collection did not include data concerning myocardial tissue Doppler or strain data, nor data concerning diastolic heart function.

The clinical data of 10 consecutive young adults ( 8 females and 2 males) with the mean age of 15 years, hospitalized with other psychiatric disorders, and with no evidence of heart abnormalities and with no medication on admission, served as a control group, and their clinical data were collected and summarized.

The mean age was $16 \pm 3$ (range 11.5 to 20 years). Mean weight loss was $13.5 \pm 4 \mathrm{~kg}$ (range 6 to $26 \mathrm{~kg}$ ) and mean BMI was $15.4 \pm 3.2 \mathrm{~kg} / \mathrm{m}^{2}$ (range 10.9 to $20 \mathrm{~kg} / \mathrm{m}^{2}$ ).

Bradycardia among patients with AN was defined as a $\mathrm{HR}<50 \mathrm{bpm}$ during day time and $<45 \mathrm{bpm}$ during night time. ${ }^{19}$ Each patient had a clinical follow-up after 6 months, where ECG was undertaken, and a telephonic follow-up, a year after hospital discharge.

\section{Statistical Analysis}

Quantity data were described by mean, standard deviation, median, and range. Quality data presented as frequencies and percentages. Sensitivity and specificity were calculated.

For comparisons between groups of quantity data, independent sample $t$ test or Wilcoxon rank-sum test were used, as appropriate.

For comparisons of qualitative data, Fisher exact test was performed.

Correlations examined by Pearson correlation coefficient test or Spearman correlation coefficient test, as appropriate.

Sensitivity and specificity measures were selected as the appropriate indices for this type of study.

\section{Results}

Descriptive demographic, auscultatory, ECG, and echocardiographic findings of 23 AN patients and 10 non-AN patients are displayed in - Tables 1-8.

Sixteen out of 23 (69\%) patients showed HR $<50$ bpm at presentation.

During 24 hours of Holter monitoring, 22 out of 23 (95\%) patients showed prolong period (more than 180 minutes) of bradycardia where the mean lowest HR of all patients was $44 \pm 6 \mathrm{bpm}$ (range 26 to $68 \mathrm{bpm}$ ) and the mean lowest HR of the control group was $74 \mathrm{bpm}$ (range 66 to $99 \mathrm{bpm})(p<0.001$ ).

The leading ECG findings were sinus and nodal bradycardia (-Figs. 1-3), with no evidence of other arrhythmias. Only few ventricular premature beats were recorded in four patients with AN and in one patient with non-AN. QT and $\mathrm{QT}_{\mathrm{C}}$ intervals were in the normal range in all patients (-Tables 5 and $\mathbf{6}$ ).

Using echocardiography, MVP (-Fig. 4) was found in three patients, mitral regurgitation in four patients, and mild aortic stenosis in one patient. All patients in the control group had a normal echocardiogram (-Table 8). Laboratory data were in the normal range in both groups. Summary of leading clinical data and statistical analysis are presented in - Table $\mathbf{9}$. There 
Table 1 Demographic and clinical parameters (AN patients) on admission

\begin{tabular}{|c|c|c|c|c|c|}
\hline Patient no. & HR (bmp) & Diagnosis & BMI & Age (years) & Sex \\
\hline 1 & 38 & AN & 16.5 & 13 & $\mathrm{~F}$ \\
\hline 2 & 34 & AN & 13 & 17 & $\mathrm{~F}$ \\
\hline 3 & 36 & AN & 19.5 & 14 & $\mathrm{~F}$ \\
\hline 4 & 40 & AN & 16.3 & 16 & $\mathrm{~F}$ \\
\hline 5 & 38 & AN & 10.9 & 17 & $\mathrm{~F}$ \\
\hline 6 & 26 & AN & 17 & $19^{a}$ & $\mathrm{~F}$ \\
\hline 7 & 41 & AN & 17 & 14 & $\mathrm{~F}$ \\
\hline 8 & 28 & AN & 18.7 & 14 & $\mathrm{~F}$ \\
\hline 9 & 39 & AN & 17 & $20^{a}$ & $\mathrm{~F}$ \\
\hline 10 & 45 & AN & 12.2 & 15 & $\mathrm{~F}$ \\
\hline 11 & 60 & AN & 15 & 14 & $\mathrm{~F}$ \\
\hline 12 & 68 & AN & 19 & $20^{a}$ & $\mathrm{~F}$ \\
\hline 13 & 50 & AN & 18 & 15 & $\mathrm{~F}$ \\
\hline 14 & 43 & AN & 17 & 16 & $\mathrm{~F}$ \\
\hline 15 & 50 & AN & 14.8 & 16 & $\mathrm{~F}$ \\
\hline 16 & 34 & AN & 13.4 & 15 & $\mathrm{~F}$ \\
\hline 17 & 38 & AN & 14 & 11.5 & $\mathrm{M}$ \\
\hline 18 & 65 & AN & 20 & 17.5 & $\mathrm{~F}$ \\
\hline 19 & 65 & AN & 14.7 & 16.5 & $\mathrm{~F}$ \\
\hline 20 & 57 & AN & 14 & 16 & $\mathrm{~F}$ \\
\hline 21 & 43 & AN & 15.5 & 13 & $\mathrm{M}$ \\
\hline 22 & 44 & AN & 13 & 17 & $\mathrm{M}$ \\
\hline 23 & 38 & AN & 14.13 & 15 & $\mathrm{~F}$ \\
\hline
\end{tabular}

Abbreviations: AN, anorexia nervosa; BMI, body mass index; F, female; HR, heart rate (bpm); M, male.

${ }^{a}$ From the Department of Internal Medicine.

$$
\mathrm{BMI}=\frac{\text { Mass }(\mathrm{kg})}{[\operatorname{Height}(\mathrm{m})]^{2}}
$$

Table 2 Demographic and clinical parameters (non-AN patients) on admission

\begin{tabular}{|l|l|l|l|l|l|}
\hline Patient no. & HR (bmp) & Diagnosis & BMI & Age (years) & Sex \\
\hline 1 & 72 & Other (no AN) & 21.4 & 12 & $\mathrm{~F}$ \\
\hline 2 & 99 & Other (no AN) & 31.4 & 15 & $\mathrm{~F}$ \\
\hline 3 & 76 & Other (no AN) & 23.4 & 15 & $\mathrm{M}$ \\
\hline 4 & 69 & Other (no AN) & 29.2 & 17 & $\mathrm{M}$ \\
\hline 5 & 84 & Other (no AN) & 18.7 & 14 & $\mathrm{~F}$ \\
\hline 6 & 66 & Other (no AN) & 32.2 & 17 & $\mathrm{~F}$ \\
\hline 7 & 68 & Other (no AN) & 32.7 & 17 & $\mathrm{~F}$ \\
\hline 8 & 67 & Other (no AN) & 27.3 & 15 & $\mathrm{~F}$ \\
\hline 9 & 68 & Other (no AN) & 31.6 & 14 & $\mathrm{~F}$ \\
\hline 10 & 71 & Other (no AN) & 19.4 & $\mathrm{~F}$ \\
\hline
\end{tabular}

Abbreviations: AN, anorexia nervosa; BMI, body mass index; F, female; HR, heart rate (bpm); M, male. 
86 Bradycardia in Anorexia Nervosa Yahalom et al.

Table 3 Clinical (auscultatory) findings in AN patients

\begin{tabular}{|c|c|c|}
\hline Patient no. & Systolic murmur & Systolic click \\
\hline 1 & No & No \\
\hline 2 & No & No \\
\hline 3 & No & No \\
\hline 4 & No & No \\
\hline 5 & No & No \\
\hline 6 & No & No \\
\hline 7 & No & No \\
\hline 8 & No & No \\
\hline 9 & No & Yes \\
\hline 10 & Yes & Yes \\
\hline 11 & No & No \\
\hline 12 & No & Yes \\
\hline 13 & No & No \\
\hline 14 & No & No \\
\hline 15 & No & No \\
\hline 16 & No & Yes \\
\hline 17 & No & Yes \\
\hline 18 & Yes & Yes \\
\hline 19 & Yes & Yes \\
\hline 20 & No & Yes \\
\hline 21 & No & Yes \\
\hline 22 & Yes & No \\
\hline 23 & No & No \\
\hline
\end{tabular}

Abbreviation: AN, anorexia nervosa.

Table 4 Clinical (auscultatory) findings in non-AN patients

\begin{tabular}{|l|l|l|}
\hline Patient no. & Systolic murmur & Systolic click \\
\hline 1 & No & Yes \\
\hline 2 & No & No \\
\hline 3 & Yes & No \\
\hline 4 & No & No \\
\hline 5 & No & No \\
\hline 6 & No & No \\
\hline 7 & Yes & No \\
\hline 8 & No & No \\
\hline 9 & No & Yes \\
\hline 10 & No & Yes \\
\hline
\end{tabular}

Abbreviation: AN, anorexia nervosa.
Table 5 ECG and Holter ECG data in AN patients

\begin{tabular}{|c|c|c|}
\hline Patient no. & $\begin{array}{l}\text { Ventricular } \\
\text { arrhythmias }\end{array}$ & $\mathrm{QT}_{\mathrm{c}}$ interval (s) \\
\hline 1 & No & 0.44 \\
\hline 2 & No & 0.40 \\
\hline 3 & No & 0.36 \\
\hline 4 & No & 0.40 \\
\hline 5 & No & 0.38 \\
\hline 6 & Few VPBs & 0.44 \\
\hline 7 & No & 0.44 \\
\hline 8 & No & 0.40 \\
\hline 9 & No & 0.40 \\
\hline 10 & No & 0.36 \\
\hline 11 & $1 \mathrm{VPB}$ & 0.39 \\
\hline 12 & No & 0.36 \\
\hline 13 & No & 0.40 \\
\hline 14 & $1 \mathrm{VPB}$ & 0.40 \\
\hline 15 & No & 0.38 \\
\hline 16 & No & 0.40 \\
\hline 17 & No & 0.36 \\
\hline 18 & $\begin{array}{l}\text { Few VPBs and } \\
\text { couplets }\end{array}$ & 0.40 \\
\hline 19 & Few VPBs & 0.36 \\
\hline 20 & No & 0.40 \\
\hline 21 & No & 0.40 \\
\hline 22 & No & 0.40 \\
\hline 23 & No & 0.40 \\
\hline
\end{tabular}

Abbreviations: AN, anorexia nervosa; ECG, electrocardiographic; VPBs, ventricular premature beats.

Table 6 ECG and Holter ECG data in non-AN patients

\begin{tabular}{|l|l|l|}
\hline Patient no. & $\begin{array}{l}\text { Ventricular } \\
\text { arrhythmias }\end{array}$ & QT $_{\mathbf{c}}$ interval (s) \\
\hline 1 & No & 0.36 \\
\hline 2 & Few VPBs & 0.32 \\
\hline 3 & No & 0.32 \\
\hline 4 & No & 0.34 \\
\hline 5 & No & 0.30 \\
\hline 6 & No & 0.32 \\
\hline 7 & No & 0.32 \\
\hline 8 & No & 0.36 \\
\hline 9 & No & 0.36 \\
\hline 10 & No & 0.34 \\
\hline
\end{tabular}

Abbreviations: AN, anorexia nervosa; ECG, electrocardiographic; VPBs, ventricular premature beats. 
Table 7 Echocardiographic data in AN patients

\begin{tabular}{|c|c|c|c|}
\hline Patient no. & $\begin{array}{l}\text { Ventricular (LV and RV) } \\
\text { global systolic function }\end{array}$ & $\begin{array}{l}\text { Valvular Doppler } \\
\text { study }\end{array}$ & $\begin{array}{l}\text { Pericardial } \\
\text { effusion }\end{array}$ \\
\hline 1 & $\mathrm{~N}$ & $\mathrm{~N}$ & No \\
\hline 2 & $\mathrm{~N}$ & $\mathrm{~N}$ & No \\
\hline 3 & $\mathrm{~N}$ & $\mathrm{~N}$ & No \\
\hline 4 & $\mathrm{~N}$ & $\mathrm{~N}$ & No \\
\hline 5 & $\mathrm{~N}$ & $\mathrm{~N}$ & No \\
\hline 6 & $\mathrm{~N}$ & Mild MR & No \\
\hline 7 & $\mathrm{~N}$ & $\mathrm{~N}$ & No \\
\hline 8 & $\mathrm{~N}$ & $\mathrm{~N}$ & No \\
\hline 9 & $\mathrm{~N}$ & $\begin{array}{l}\text { MVP and } \\
\text { mild MR }\end{array}$ & No \\
\hline 10 & $\mathrm{~N}$ & Mild MR & No \\
\hline 11 & $\mathrm{~N}$ & $\mathrm{~N}$ & No \\
\hline 12 & $\mathrm{~N}$ & Mild MR & No \\
\hline 13 & $\mathrm{~N}$ & $\mathrm{~N}$ & No \\
\hline 14 & $\mathrm{~N}$ & $\mathrm{~N}$ & No \\
\hline 15 & $\mathrm{~N}$ & $\mathrm{~N}$ & No \\
\hline 16 & $\mathrm{~N}$ & Mild MR & No \\
\hline 17 & $\mathrm{~N}$ & $\mathrm{~N}$ & No \\
\hline 18 & $\mathrm{~N}$ & $\begin{array}{l}\text { Mild AS and } \\
\text { mild AR }\end{array}$ & No \\
\hline 19 & $\mathrm{~N}$ & $\begin{array}{l}\text { MVP and } \\
\text { mild MR }\end{array}$ & No \\
\hline 20 & $\mathrm{~N}$ & $\mathrm{~N}$ & No \\
\hline 21 & $\mathrm{~N}$ & $\mathrm{~N}$ & No \\
\hline 22 & $\mathrm{~N}$ & $\begin{array}{l}\text { MVP and } \\
\text { mild MR }\end{array}$ & No \\
\hline 23 & $\mathrm{~N}$ & $\mathrm{~N}$ & Minimal \\
\hline
\end{tabular}

Abbreviations: AN, anorexia nervosa; AR, aortic regurgitation; AS, aortic stenosis; LV, left ventricle; MR, mitral regurgitation; MVP, mitral valve prolapse; N, normal; RV, right ventricle.

were no differences between the two groups concerning age, gender, and auscultatory findings. BMI, $\mathrm{HR}$, and $\mathrm{QT}_{\mathrm{c}}$ were statistically different $(p$ value $<0.001)$. Total number of patients in AN group with bradycardia less than $50 / \mathrm{min}$ was16/23 (69.6\%) with sensitivity of $69.6 \%$ and specificity of $100 \%$ (-Table 10).

A positive correlation was found between $\mathrm{HR}$ and $\mathrm{BMI}$ ( - Fig. 5A) and a negative one between $\mathrm{QT}_{\mathrm{c}}$ and $\mathrm{BMI}$ ( - Fig. 5B ) and $\mathrm{QT}_{\mathrm{C}}$ and $\mathrm{HR}$ (-Fig. 5C).

\section{Clinical Course and Follow-Up}

No patient needed positive chronotropic pharmacological intervention or pacemaker therapy. Under refeeding and psychological support, gradual increase in HR was observed. Six months after discharge, the mean HR increased from $48 \pm 12$ to $65 \pm 6 \mathrm{bpm}$. No cardiac-related complications were recorded after 1 year of follow-up.

\section{Discussion}

Our study demonstrated the high prevalence of bradycardia among AN patients. This simple and "easy to get" clinical finding may be used as a marker for the possible presence of this entity, especially among hidden cases.

Similar to other reports, ${ }^{19-21}$ our article reconfirms the observation that bradycardia is a common finding among patients with AN.

Among psychosocial disturbances, eating disorders has the highest mortality rate. ${ }^{9}$ A 21 -year follow-up of 34 patients with AN showed that $16 \%$ of them died of eating disordersrelated complications. ${ }^{22}$ Most patients with AN are generally asymptomatic even in the presence of bradycardia, unless it is associated with hypotension or other arrhythmias. However, even in apparently asymptomatic patients, bradycardia can be a precursor of a potentially lethal arrhythmia. 
Table 8 Echocardiographic data in non-AN patients

\begin{tabular}{|l|l|l|l|}
\hline Patient no. & $\begin{array}{l}\text { Ventricular (LV and RV) } \\
\text { global systolic function }\end{array}$ & $\begin{array}{l}\text { Valvular Doppler } \\
\text { study }\end{array}$ & $\begin{array}{l}\text { Pericardial } \\
\text { effusion }\end{array}$ \\
\hline 1 & N & N & No \\
\hline 2 & N & N & No \\
\hline 3 & N & N & No \\
\hline 4 & N & N & No \\
\hline 5 & N & N & No \\
\hline 6 & N & N & No \\
\hline 7 & N & N & No \\
\hline 8 & N & N & No \\
\hline 9 & N & N & No \\
\hline 10 & N & N & No \\
\hline
\end{tabular}

Abbreviations: AN, anorexia nervosa; AR, aortic regurgitation; AS, aortic stenosis; LV, left ventricle; MR, mitral regurgitation; MVP, mitral valve prolapse; $\mathrm{N}$, normal; RV, right ventricle.

The absence of lethal arrhythmia in our group is most probably related to either a short follow-up period and/or clinical improvement in their medical status.

Similar to our findings, it was postulated that refeeding should be gradual, thus preventing the refeeding syndrome, characterized by tachycardia, heart failure, and electrolytes abnormalities, that can lead to cardiac arrest. ${ }^{23}$

Cardiovascular complications are common in patients with AN, but sinus bradycardia has been described as the most common cardiovascular physical finding and the most common arrhythmia in this group of patients. ${ }^{19}$ It is impor- tant to appreciate its significance in this clinical setting, because it may be associated with sudden death, especially in the presence of other arrhythmias or ECG abnormalities, such as prolonged $\mathrm{QT}_{\mathrm{c}}$ interval secondary to electrolyte disturbances (such as hypokalemia, hypomagnesemia, hypophosphatemia), or due to congenital abnormalities such as long QT syndrome. ${ }^{20}$

The mechanism of bradycardia in AN is thought to be a physiological adaptation to increased vagal tone and decreased metabolism of energy utilization, due to the low caloric intake. ${ }^{21}$ It has been postulated that bradycardia

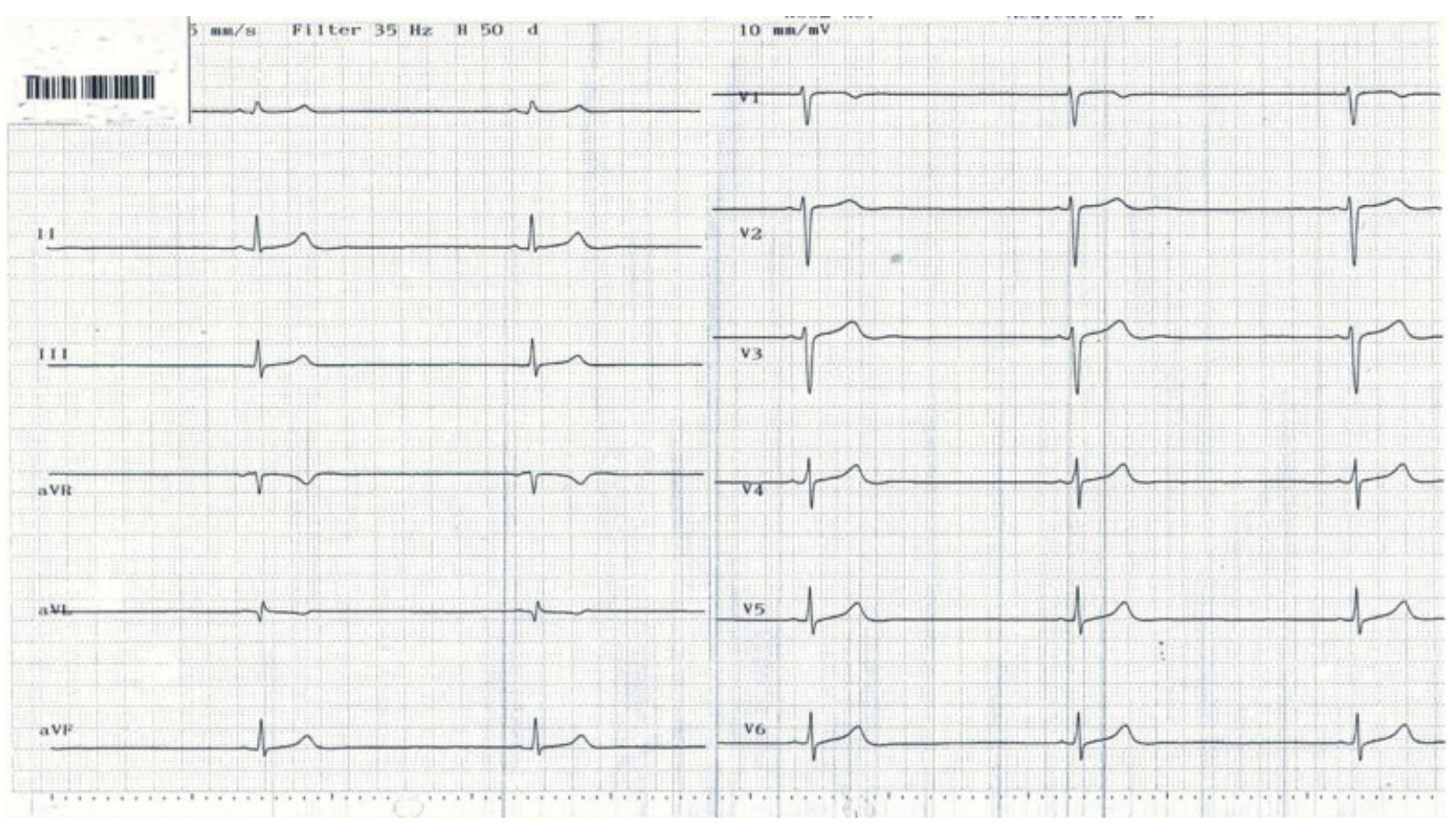

Fig. 1 Bradycardia of 31/bpm in 19-year-old female with anorexia nervosa. 


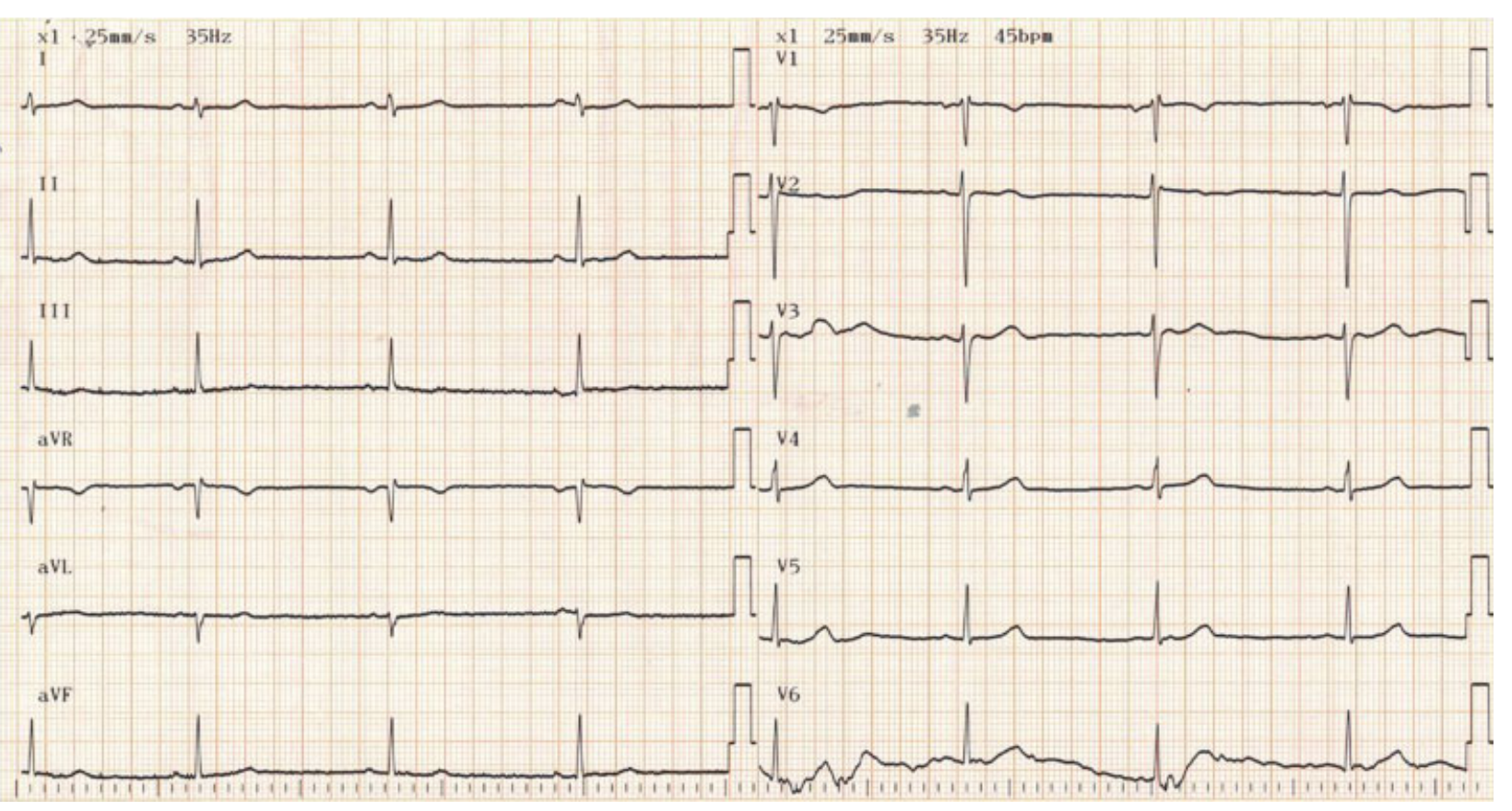

Fig. 2 Bradycardia of 45/bpm in 16-year-old female with anorexia nervosa.

results from structural changes in the heart, such as a decrease in the left ventricular muscle mass, secondary to malnutrition. ${ }^{24}$ It was suggested that in patients with atrophic hearts, bradycardia may be a compensatory mechanism to prevent heart failure. Vázquez et al described decreased glycogen content of myocardial cells and cellular atrophy that can contribute to the bradycardia. ${ }^{25}$
It was emphasized that the mechanism for bradycardia in patients with AN is different from bradycardia seen in athletes. $^{26}$

There is evidence that the bradycardia of AN is reversible, and that following treatment, clinical improvement, and weight gain, the bradycardia is lessened and ameliorated at rest and during exercise. ${ }^{1,27}$ It is important to note that

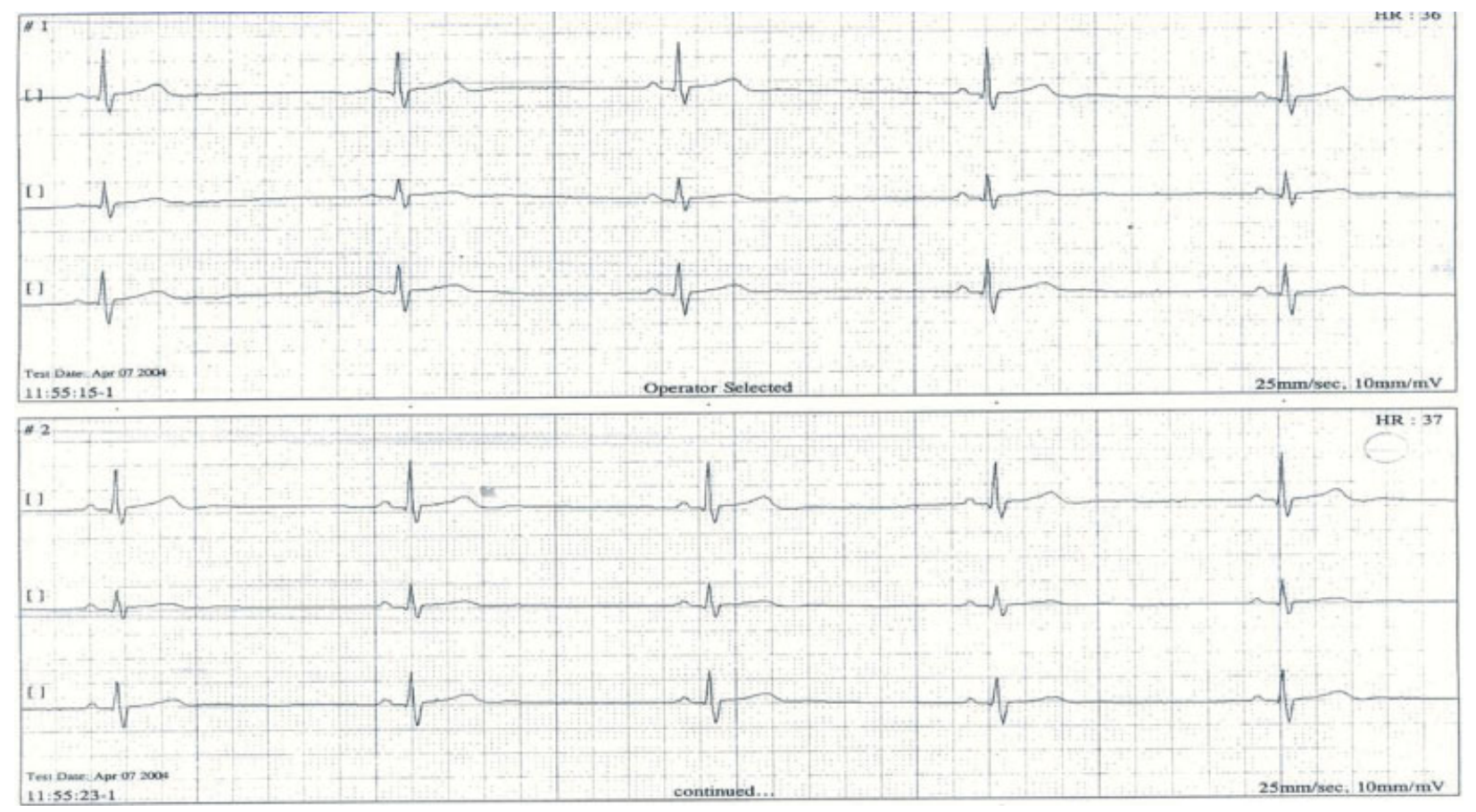

Fig. 3 Bradycardia of 38/bpm in 17-year-old female with anorexia nervosa. 

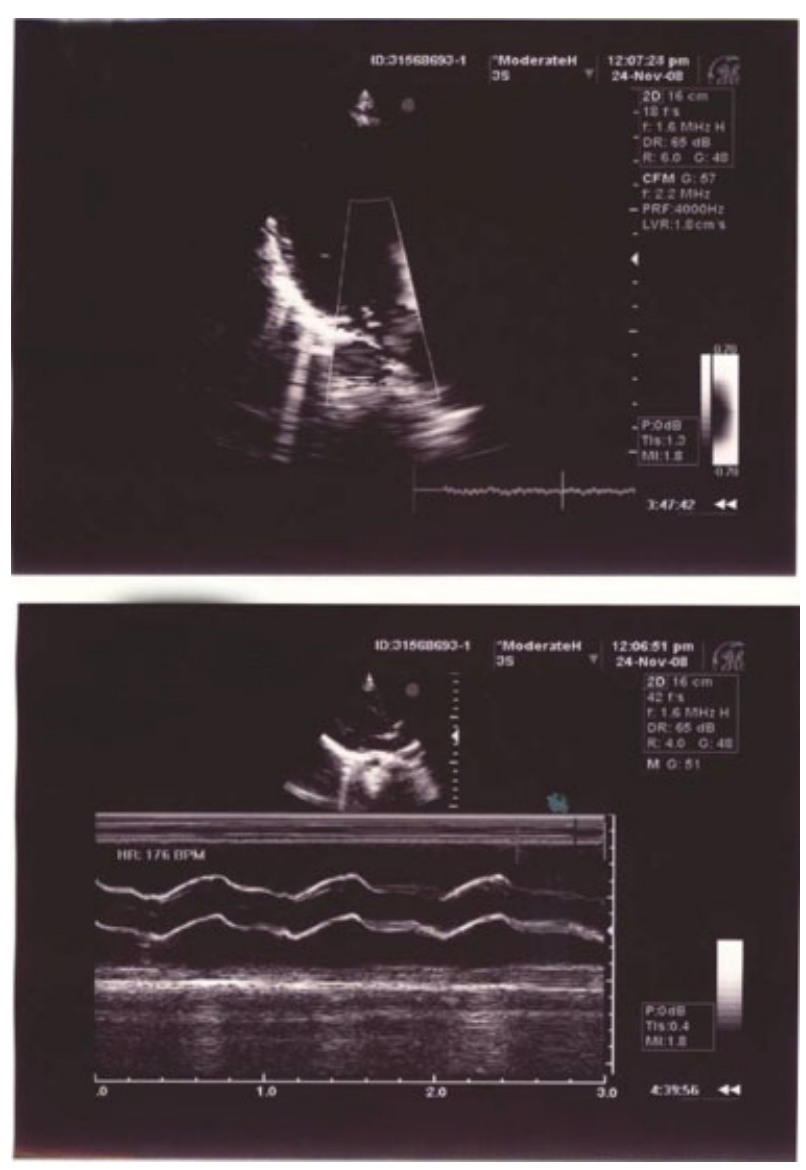

Fig. 4 Echocardiogram in 12-year-old female with anorexia nervosademonstrating mitral valve prolapse and mitral regurgitation. bradycardia among patients with weight loss could originate from conduction system disease that eventually needs permanent pacemaker therapy. ${ }^{28-30}$

It is well known that denial of being ill is common in patients with AN and therefore, symptoms associated with AN, such as fatigue, are not reported. The Society for Adolescent Medicine recommends referring these patients to hospital when daytime HR is $<50 \mathrm{bpm}$ and night HR is $<45 \mathrm{bpm} .^{29,31}$

Based on our data, it is recommended that physicians from different disciplines, family practitioners, pediatricians, gynecologists, primary care, endocrinologists, and military physicians who take care of adolescents, should be aware of and identify cardiovascular findings, particularly bradycardia $(\mathrm{HR}<50 \mathrm{bpm})$, in adolescents who may have the diagnosis of AN. In other words, bradycardia may be the first sign of a possible eating disorder, both AN and bulimic nervosa.

It was recommended that patients with AN who are admitted to the hospital with a HR of less than $35 \mathrm{bpm}$ should have continuous monitoring. Medication such as inotropic drugs should be avoided and are contraindicated because of the possibility of additional potential ventricular arrhythmias. $^{19,32}$

\section{Summary and Conclusions}

Bradycardia is a common finding in AN. Its existence in young adults, especially young females with weight loss, represents an ominous sign for cardiac sudden death.

The presence of bradycardia among adolescents raises the possible diagnosis of an eating disorder, that is not always obvious, and that can be treated early and promptly in time. Thus it may prevent premature sudden death or disability in the future lives of these young patients.

Table 9 Summary of demographic and clinical parameters in AN and non-AN patients

\begin{tabular}{|c|c|c|c|c|}
\hline & & AN $(n=23)$ & $\begin{array}{l}\text { Other diagnosis } \\
\text { Non-AN }(n=10)\end{array}$ & $p$ value \\
\hline \multirow{4}{*}{$\begin{array}{l}\text { Age } \\
\text { (Years) }\end{array}$} & Mean & 15.7 & 14.8 & \multirow[t]{4}{*}{$0.364^{\mathrm{a}}$} \\
\hline & Standard deviation & 2.2 & 1.9 & \\
\hline & Median & 16 & 15 & \\
\hline & Range & $11.5-20$ & $12-17$ & \\
\hline \multirow[t]{2}{*}{ Gender } & $M$ & $\begin{array}{l}3 \\
13.0 \%\end{array}$ & $\begin{array}{l}2 \\
20 \%\end{array}$ & \multirow[t]{2}{*}{$0.727^{b}$} \\
\hline & $\mathrm{F}$ & $\begin{array}{l}20 \\
87 \%\end{array}$ & $\begin{array}{l}8 \\
80 \%\end{array}$ & \\
\hline \multirow{4}{*}{$\begin{array}{l}\text { BMI } \\
\left(\mathrm{kg} / \mathrm{m}^{2}\right)\end{array}$} & Mean & 15.6 & 26.7 & \multirow[t]{4}{*}{$p<0.001^{c}$} \\
\hline & Standard deviation & 2.4 & 5.5 & \\
\hline & Median & 15.5 & 28.25 & \\
\hline & Range & $10.9-20$ & $18.7-33.5$ & \\
\hline
\end{tabular}


Table 9 (Continued)

\begin{tabular}{|c|c|c|c|c|}
\hline & & AN $(n=23)$ & $\begin{array}{l}\text { Other diagnosis } \\
\text { Non-AN }(n=10)\end{array}$ & $p$ value \\
\hline \multirow{4}{*}{$\begin{array}{l}\text { HR } \\
\text { (bpm) }\end{array}$} & Mean & 44.3 & 74 & \multirow[t]{4}{*}{$p<0.001^{c}$} \\
\hline & Standard deviation & 11.6 & 10.3 & \\
\hline & Median & 41 & 70 & \\
\hline & Range & $26-68$ & $66-99$ & \\
\hline \multirow[t]{4}{*}{$\mathrm{QT}_{\mathrm{c}}(\mathrm{s})$} & Mean & 0.39 & 0.34 & \multirow[t]{4}{*}{$p<0.001^{a}$} \\
\hline & Standard deviation & 0.024 & 0.018 & \\
\hline & Median & 0.40 & 0.33 & \\
\hline & Range & $0.36-0.44$ & $0.32-0.36$ & \\
\hline \multirow[t]{2}{*}{$\begin{array}{l}\text { Ventricular arrhythmias } \\
\text { (on Holter) }\end{array}$} & No & $\begin{array}{l}18 \\
78.3 \%\end{array}$ & $\begin{array}{l}9 \\
90 \%\end{array}$ & \multirow[t]{2}{*}{$0.395^{d}$} \\
\hline & Yes & $\begin{array}{l}5 \\
21.7 \%\end{array}$ & $\begin{array}{l}1 \\
10 \%\end{array}$ & \\
\hline \multirow[t]{2}{*}{$\begin{array}{l}\text { Pericardial effusion } \\
\text { (on echocardiogram) }\end{array}$} & No & $\begin{array}{l}22 \\
95.7 \%\end{array}$ & $\begin{array}{l}10 \\
100 \%\end{array}$ & \multirow[t]{2}{*}{$0.697^{d}$} \\
\hline & Yes & $\begin{array}{l}1 \\
4.3 \%\end{array}$ & $\begin{array}{l}0 \\
0 \%\end{array}$ & \\
\hline \multirow[t]{2}{*}{$\begin{array}{l}\text { MVP on valvular } \\
\text { Doppler study }\end{array}$} & No & $\begin{array}{l}20 \\
87 \%\end{array}$ & $\begin{array}{l}10 \\
100 \% \\
\end{array}$ & \multirow[t]{2}{*}{$0.325^{d}$} \\
\hline & MVP & $\begin{array}{l}3 \\
13 \%\end{array}$ & $\begin{array}{l}0 \\
0 \%\end{array}$ & \\
\hline \multirow[t]{2}{*}{$\begin{array}{l}\text { Ventricular global systolic } \\
\text { function (LV and RV) }\end{array}$} & Normal & $\begin{array}{l}23 \\
100 \%\end{array}$ & $\begin{array}{l}10 \\
100 \%\end{array}$ & \\
\hline & Not normal & $\begin{array}{l}0 \\
0 \%\end{array}$ & $\begin{array}{l}0 \\
0 \%\end{array}$ & \\
\hline \multirow[t]{2}{*}{ Systolic murmur } & No & $\begin{array}{l}19 \\
82.6 \%\end{array}$ & $\begin{array}{l}8 \\
80 \% \\
\end{array}$ & \multirow[t]{2}{*}{$\begin{array}{l}1.000^{\mathrm{b}} \\
0.605^{\mathrm{d}}\end{array}$} \\
\hline & Yes & $\begin{array}{l}4 \\
17.4 \%\end{array}$ & $\begin{array}{ll}2 \\
20 \%\end{array}$ & \\
\hline \multirow[t]{2}{*}{ Systolic click } & No & $\begin{array}{l}14 \\
60.9 \%\end{array}$ & $\begin{array}{l}8 \\
80 \%\end{array}$ & \multirow[t]{2}{*}{$0.256^{\mathrm{d}}$} \\
\hline & Yes & $\begin{array}{l}9 \\
39.1 \%\end{array}$ & $\begin{array}{l}2 \\
20 \%\end{array}$ & \\
\hline
\end{tabular}

Abbreviations: AN, anorexia nervosa; BMI, body mass index; HR, heart rate; MVP, mitral valve prolapse; LV, left ventricle; RV, right ventricle. a Wilcoxon rank-sum test, two-sided.

bFisher exact test, two-sided.

'Wilcoxon rank-sum test, one-sided.

${ }^{\mathrm{d}}$ Fisher exact test, one-sided.

Table 10 No. of patients with bradycardia and anorexia nervosa

\begin{tabular}{|l|l|l|}
\hline & Other diagnosis & Anorexia \\
\hline HR $<50$ & 0 & 16 \\
& $0 \%$ & $69.6 \%$ \\
\hline HR $\geq 50$ & 10 & 7 \\
& $100 \%$ & $30.4 \%$ \\
\hline Total & 10 & 23 \\
& $100 \%$ & $100 \%$ \\
\hline
\end{tabular}

Abbreviation: $\mathrm{HR}$, heart rate.

Note: Sensitivity $=69.6 \%$ and specificity $=100 \%$. 

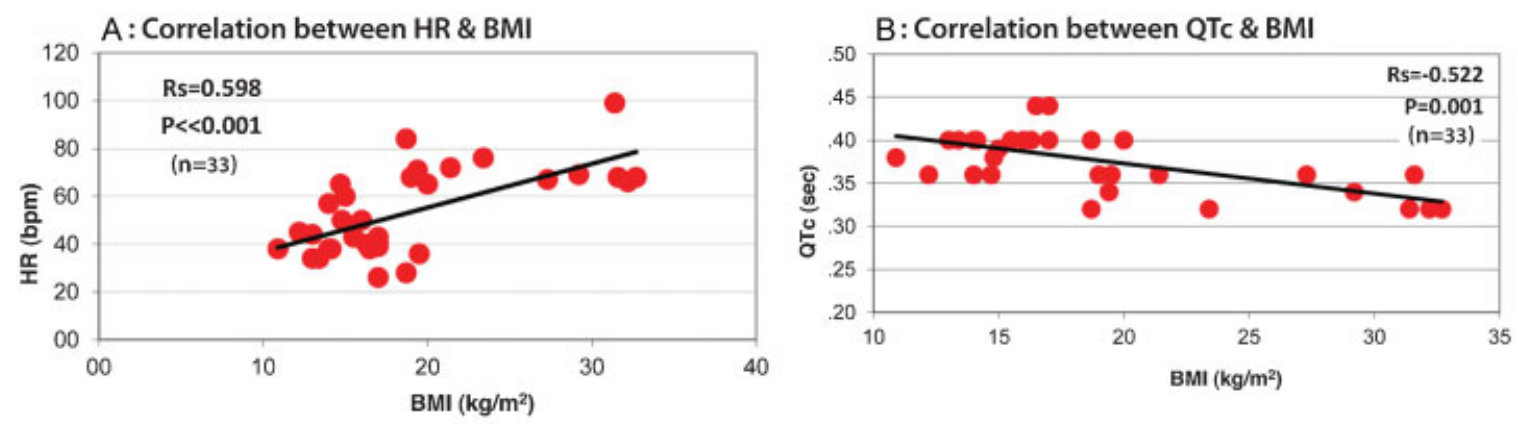

C : Correlation between QTc \& HR

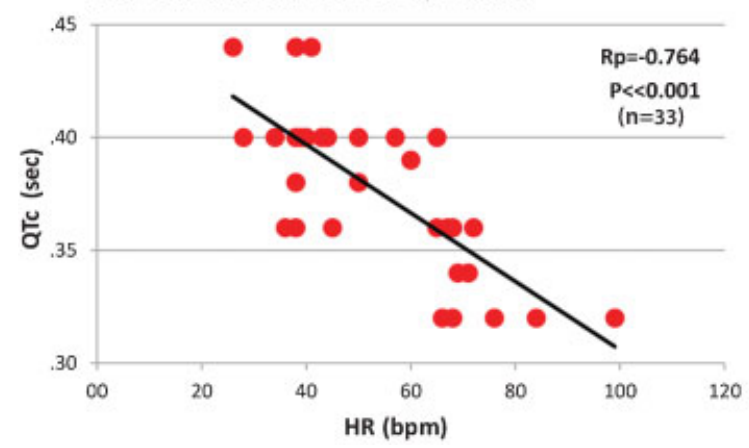

\section{References}

1 American Heart Association. Bradycardia. Available at: http://www. heart.org/HEARTORG/Conditions/Arrhythmia/AboutArrhythmia/ Bradycardia_UCM_302016_Article.jsp. Accessed September 6, 2012

2 Ulger Z, Gürses D, Ozyurek AR, Arikan C, Levent E, Aydoğdu S. Follow-up of cardiac abnormalities in female adolescents with anorexia nervosa after refeeding. Acta Cardiol 2006;61(1):43-49

3 Ravaldi C, Vannacci A, Ricca V. Complicanze cardiache dell'anoressia nervosa. Recenti Prog Med 2003;94(6):267-270

4 McCallum K, Bermudez O, Ohlemeyer C, Tyson E, Portilla M, Ferdman B. How should the clinician evaluate and manage the cardiovascular complications of anorexia nervosa? Eat Disord 2006;14(1):73-80

5 Steinhausen HC. The outcome of anorexia nervosa in the 20th century. Am J Psychiatry 2002;159(8):1284-1293

6 Sullivan PF. Mortality in anorexia nervosa. Am J Psychiatry 1995;152(7):1073-1074

7 Katzman DK. Medical complications in adolescents with anorexia nervosa: a review of the literature. Int J Eat Disord 2005;37(Suppl): S52-S59, discussion S87-S89

8 Mont L, Castro J, Herreros B, et al. Reversibility of cardiac abnormalities in adolescents with anorexia nervosa after weight recovery. J Am Acad Child Adolesc Psychiatry 2003;42(7):808-813

9 Casiero D, Frishman WH. Cardiovascular complications of eating disorders. Cardiol Rev 2006;14(5):227-231

10 Golden NH, Meyer W. Nutritional rehabilitation of anorexia nervosa. Goals and dangers. Int J Adolesc Med Health 2004;16(2):131-144

11 Galetta F, Franzoni F, Prattichizzo F, Rolla M, Santoro G, Pentimone F. Heart rate variability and left ventricular diastolic function in anorexia nervosa. J Adolesc Health 2003;32(6):416-421

12 Facchini M, Sala L, Malfatto G, Bragato R, Redaelli G, Invitti C. Low$\mathrm{K}+$ dependent QT prolongation and risk for ventricular arrhythmia in anorexia nervosa. Int J Cardiol 2006;106(2):170-176

13 Swenne I, Larsson PT. Heart risk associated with weight loss in anorexia nervosa and eating disorders: risk factors for QTc interval prolongation and dispersion. Acta Paediatr 1999;88(3): 304-309
14 Isner JM, Roberts WC, Heymsfield SB, Yager J. Anorexia nervosa and sudden death. Ann Intern Med 1985;102(1):49-52

15 Eckardt L, Haverkamp W, Borggrefe M, Breithardt G. Experimental models of torsade de pointes. Cardiovasc Res 1998;39(1):178-193

16 American Psychiatric Association. Diagnostic and Statistical Manual of Mental Disorders, 4th ed. Washington, DC: American Psychiatric Association; 1994

17 Otto CM, Bonow RO. Valvular heart disease. In: Bonow RO, Mann DL, Zipes DP, Libby P, eds. Braunwald's Heart Disease, Textbook of Cardiovascular Medicine, 9th ed. Philadelphia: Saunders, Elsevier Inc.; 2009:1512

18 Connolly HM, Oh JK. Echocardiography. In: Bonow RO, Mann DL, Zipes DP, Libby P, eds. Braunwald's Heart Disease, Textbook of Cardiovascular Medicine, 9th ed. Philadelphia: Saunders, Elsevier Inc.; 2009:200-270

19 Portilla MG. Bradycardia: an important physical finding in anorexia nervosa. J Ark Med Soc 2011;107(10):206-208

20 Vanderdonckt O, Lambert M, Montero MC, Boland B, Brohet C. The 12-lead electrocardiogram in anorexia nervosa: A report of 2 cases followed by a retrospective study. J Electrocardiol 2001;34(3): 233-242

21 Kollai M, Bonyhay I, Jokkel G, Szonyi L. Cardiac vagal hyperactivity in adolescent anorexia nervosa. Eur Heart J 1994;15(8): $1113-1118$

22 Löwe B, Zipfel S, Buchholz C, Dupont Y, Reas DL, Herzog W. Longterm outcome of anorexia nervosa in a prospective 21-year followup study. Psychol Med 2001;31(5):881-890

23 Kohn MR, Golden NH, Shenker IR. Cardiac arrest and delirium: presentations of the refeeding syndrome in severely malnourished adolescents with anorexia nervosa. J Adolesc Health 1998;22 (3):239-243

24 Gottdiener JS, Gross HA, Henry WL, Borer JS, Ebert MH. Effects of self-induced starvation on cardiac size and function in anorexia nervosa. Circulation 1978;58(3 Pt 1):425-433

25 Vázquez M, Olivares JL, Fleta J, Lacambra I, González M. Alteraciones cardiologicas en mujeres adolescentes con anorexia nerviosa. Rev Esp Cardiol 2003;56(7):669-673 
26 Bjørnstad H, Storstein L, Meen HD, Hals O. Electrocardiographic findings in athletic students and sedentary controls. Cardiology 1991;79(4):290-305

27 Olivares JL, Vázquez M, Fleta J, Moreno LA, Pérez-González JM, Bueno M. Cardiac findings in adolescents with anorexia nervosa at diagnosis and after weight restoration. Eur J Pediatr 2005; 164(6):383-386

28 Tarlet JM, Boccara G, Foltzer E, et al. [Intrinsic sinus node dysfunction in adolescence during anorexia nervosa]. Arch Mal Coeur Vaiss 1997;90(11):1545-1548

29 López-Guzmán A, Taboada F, Alvarez Escolá C. [Sinus bradycardia in anorexia nervosa]. Nutr Hosp 2002;17(1):46-47
30 Kanbur NÖ, Goldberg E, Pinhas L, Hamilton RM, Clegg R, Katzman DK. Second-degree atrioventricular block (Mobitz Type I) in an adolescent with anorexia nervosa: intrinsic or acquired conduction abnormality. Int J Eat Disord 2009;42(6): $575-578$

31 Golden NH, Katzman DK, Kreipe RE, et al; Society For Adolescent Medicine. Eating disorders in adolescents: position paper of the Society for Adolescent Medicine. J Adolesc Health 2003;33 (6):496-503

32 Harris JP, Kreipe RE, Rossbach CN. QT prolongation by isoproterenol in anorexia nervosa. J Adolesc Health 1993;14(5): 390-393 